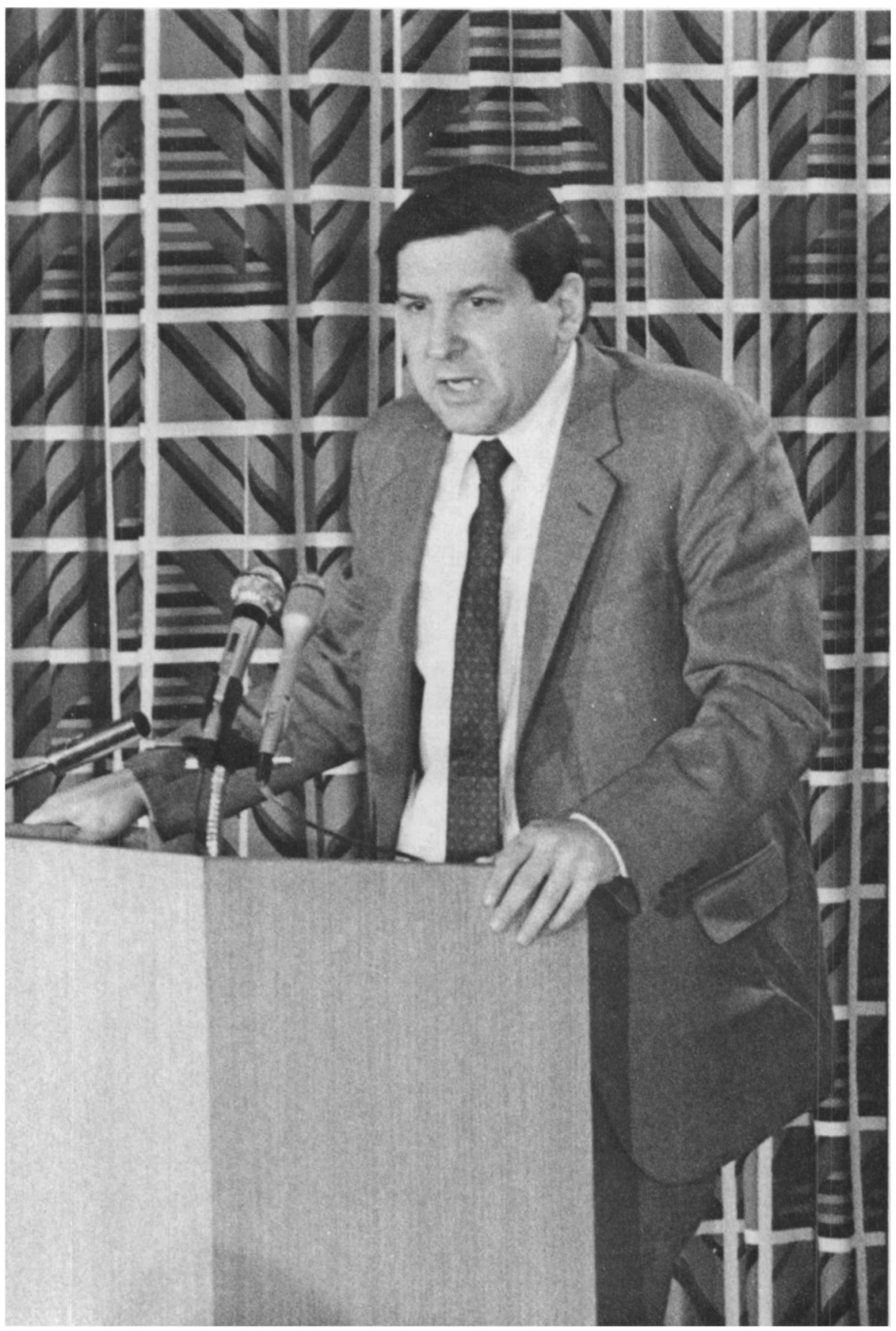

IN MEMORIAM

ROBERT M. COVER

1943-1986 


\section{DEDICATION: ROBERT M. COVER}

The following remarks were spoken by Guido Calabresi at the memorial service for Robert $M$. Cover. We reprint them here as an expression of the loss we all feel upon the death of this brilliant young scholar.

We are here to commemorate a life well led. We are here not so much to grieve (we need no special event or occasion for that) as to remind ourselves of those things that made Bob so special to each of us. That being reminded, we may all try to be better, more full of passion and compassion, more demanding of ourselves and understanding of others, and most of all less full of cant and hypocrisythose twin temptations to which the academy is so prone.

I loved Bob because he was a wonderful, dear, and loyal friend, but $I$ also loved him because he represented all that we strive to be. He was a superb scholar-there are none better-wide ranging, original, daring, a bit mad even, but always wise. And yet he knew how useless, how sinful scholarship is without character. He was a passionate activist. And yet he understood instinctively how destructive passion can be if it does not forgive and even love those individuals on whom it must, on whom it must, turn its fire. He was deeply devoted to his heritage. And yet he never let its great traditions exclude others, but made of them a light for all peoples, and a searing criticism of injustice everywhere, within as well as without.

These qualities made him a wonderful teacher, of course. What made him even more, though, was that he not only genuinely loved and supported his students, but that, since he did not have a pompous bone in his body, he never, ever patronized them.

He loved this school, with all its faults, because of its commitment to scholarship and decency, its abhorrence of rules, and its insane, but utterly wise, reliance on individual good will to keep it going. He understood immediately the anarchy and good faith that are essential to this place, and immediately made it his own.

He was not falsely modest. That, like pomp, is an all too common academic sin. No, he knew full well how extraordinarily able he was. He just knew how relatively unimportant even truly great ability is.

I will miss all of these qualities of Bob's more than I can express. But most of all, I think, I will miss his wry and always gentle sense of the absurd-that look, that smile, that told me again and again, "Don't you see what nonsense, what vanity, it all is," and at the same 
time that was so understanding of why humans have to persevere in such vanities. It is that smile that I see, that I seek, when I ask how he would have dealt with an issue, a problem I face. It is that gentle smile that chides me even now and says, "That's nice, but don't overdo it."

He was my friend. He taught me much much more than he ever knew. His life was cruelly short, but ultimately even that fact will fade, and what will remain, untouched and untouchable, in the words of the spiritual- "Bright shining as the sun"-is a life supremely well lived. 